\title{
Chemical and Biological Evaluation on Scopadulane-Type Diterpenoids from Scoparia dulcis of Vietnamese Origin
}

\author{
Phan Minh Giang, ${ }^{a, c}$ Phan Tong Son, ${ }^{a}$ Katsuyoshi Matsunami, ${ }^{b}$ and Hideaki OtsukA ${ }^{*, c}$ \\ ${ }^{a}$ Faculty of Chemistry, College of Natural Science, Vietnam National University; 19 Le Thanh Tong Street, Hanoi, \\ Vietnam: and ${ }^{b}$ Graduate School of Biomedical Sciences, Hiroshima University; 1-2-3 Kasumi, Minami-ku, Hiroshima \\ 734-8553, Japan. Received September 16, 2005; accepted November 29, 2005
}

From the aerial parts of Scoparia dulcis L. (Scrophulariaceae) grown in Vietnam, four scopadulane-type diterpenoids (4-7), of which 7 is new and was given the trivial name scopadulcic acid $C$, together with nine known compounds were isolated. Their structures were elucidated by spectroscopic analyses. The absolute configurations of 4-7 were ascertained by applying the modified Mosher's method to iso-dulcinol (6). The isolation of the lignans nirtetralin and niranthin for the first time from $S$. dulcis is also of chemotaxonomic interest. The cytotoxic activity in KB cells, inhibitory effect on LPS/IFN $\gamma$-induced NO production, inhibition of multidrug resistance (MDR), and antibacterial and antifungal activities of the scopadulane-type diterpenoids $4-7$ were examined in this study.

Key words Scoparia dulcis; Scrophulariaceae; scopadulane-type diterpenoid; multidrug resistance; methicillin-resistant Staphylococcus aureus

The tetracyclic diterpenoids scopadulcic acids A (1) and B (2), and dulcinol/scopadulciol (3) were isolated from the perennial herb Scoparia dulcis L. (Scrophulariaceae) as the first members of a unique group of labdane-derived diterpenoids, ${ }^{1-3)}$ which were proposed the name "scopadulane" by Hayashi et al. ${ }^{1)}$ Due to their unique carbon skeleton and interesting biological activities, scopadulane-type diterpenoids have been the focus of continuous studies on different collections of $S$. dulcis from Paraguay, Taiwan, and Bangladesh. ${ }^{4)}$ In recent years further efforts resulted in the isolation of three new natural metabolites, 4-epi-scopadulcic acid B (4), dulcidiol (5), and iso-dulcinol (6) from a Bangladeshi collection of $S$. dulcis. ${ }^{5}$ We evaluated the chemical composition of $S$. dulcis, which is cultivated for medicinal purposes in Vietnam, by a systematic extraction and isolation procedure and isolated four scopadulane-type diterpenoids, $4-7$, of which 7 is new and was given the trivial name scopadulcic acid $\mathrm{C}$, together with nine other known compounds. Antitumor and antitumor promoting activities, and inhibitory activities on the replication of herpes simplex virus type I, on the gastric proton pump, and on bone resorption stimulated by parathyroid hormone were demonstrated by scopadulcic acid B and scopadulciol. ${ }^{4}$ Disregarding the cytotoxic effects of $\mathbf{3 - 6}$ against a panel of six human stomach cancer cell lines, ${ }^{5)} \mathbf{4}-\mathbf{7}$ were tested for their cytotoxicity in KB cells. The inhibitory effect on lypopolysaccharide (LPS)/interferon- $\gamma$ (IFN $\gamma)$-induced nitric oxide (NO) production and calcein efflux studies were carried out to evaluate the potential of $4-7$ as lead compounds in cancer therapy. ${ }^{6,7)}$ The antibacterial activities of 4-7 against Escherichia coli, Bacillus subtillis, Staphylococcus aureus, and methicillin-resistant Staphylococcus aureus (MRSA) as well as antifungal activity against Candida albicans were also examined in this study.

The combined $n$-hexane- and $\mathrm{CH}_{2} \mathrm{Cl}_{2}$-soluble fractions of the $\mathrm{MeOH}$ extract from the aerial parts of $S$. dulcis were fractionated by silica gel open column chromatography (CC), reversed-phase octadecyl silica (ODS) gel CC, and preparative ODS HPLC to give diterpenoids 4-7. Moreover, nine known compounds were isolated and determined to be adren- alin, 6-methoxybenzoxazolinone, lupeol, betulinic acid, nirtetralin, niranthin, 4',5-dihydroxy-3,7-dimethoxyflavone, acacetin, and $3^{\prime}$-hydroxy-4',5,7-trimethoxyflavone by comparing their physical value $\left([\alpha]_{\mathrm{D}}\right)$ and spectroscopic data (NMR, CD) with those reported in the literature. ${ }^{8-14)}$ It is worthy of note that lupeol, nirtetralin, niranthin, 4',5-dihydroxy-3,7-dimethoxyflavone, and 3'-hydroxy-4',5,7-trimethoxyflavone were isolated for the first time from $S$. dulcis. Since triterpenoids ${ }^{9,15)}$ and flavonoids ${ }^{16,17)}$ have been isolated from $S$. dulcis, the presence of the lignans nirtetralin and niranthin is of chemotaxonomic interest.

Compound 7 was isolated as an amorphous powder and its molecular formula was determined to be $\mathrm{C}_{27} \mathrm{H}_{36} \mathrm{O}_{5}$ by negative-ion high-resolution (HR)-FAB-MS. The IR spectrum indicated the presence of carboxylic acid $\left(3592-2651 \mathrm{~cm}^{-1}\right)$, hydroxyl $\left(3430 \mathrm{~cm}^{-1}\right)$, and ester $\left(1706 \mathrm{~cm}^{-1}\right)$ functional groups. The ${ }^{1} \mathrm{H}$ - (Table 1) and ${ }^{13} \mathrm{C}-\mathrm{NMR}$ (Table 2) signals of 7 were found to be similar to those of 4-epi-scopadulcic B (4). ${ }^{5)}$ Significant differences were detected for C-8 $\left(\delta_{\mathrm{C}} 29.4\right.$, 4: 35.9$), \mathrm{C}-11\left(\delta_{\mathrm{C}} 37.8,4: 45.5\right), \mathrm{C}-12\left(\delta_{\mathrm{C}} 43.6,4: 52.5\right), \mathrm{C}-$ $14\left(\delta_{\mathrm{C}} 36.2,4: 42.6\right)$, and $\mathrm{C}-17\left(\delta_{\mathrm{C}} 23.9,4: 19.9\right)$. This was in agreement with the reduction of the carbonyl group at $\mathrm{C}$ 13 in $4\left(\delta_{\mathrm{C}} 213.4\right)$ to a hydroxyl group in $7\left[\delta_{\mathrm{H}} 3.33(\mathrm{brs})\right.$, $\delta_{\mathrm{C}}$ 74.7]. NOE correlations in the nuclear Overhauser effect spectroscopy (NOESY) of 7 between $\mathrm{H}_{3}-18\left(\delta_{\mathrm{H}} 0.93\right)$ and $\mathrm{H}-$ $5\left(\delta_{\mathrm{H}} 1.20\right)$ and H-6 $\left(\delta_{\mathrm{H}} 5.44\right)$ established the axial $(\beta)$-orientations of the carboxylic acid at $\mathrm{C}-19$ and the benzoyl group at $\mathrm{C}-6$. The $\beta$-axial orientation of the benzoyl group at $\mathrm{C}-6$ was in good agreement with the observed axial-equatorial coupling constant between H-5 and H-6 $(J=1.7 \mathrm{~Hz})$. The small coupling constant of $\mathrm{H}-13\left[\delta_{\mathrm{H}} 3.33(\mathrm{br} \mathrm{s})\right]$, which gave a NOE with $\mathrm{H}_{3}-17\left(\delta_{\mathrm{H}} 0.94\right)$, determined the axial $(\beta)$ orientation of the hydroxyl group at C-13. Thus, the structure of 7 was determined as shown in Fig. 1 and named scopadulcic acid C.

It is worthwhile noting that the absolute configurations of diterpenoids 4-6, which were previously isolated from Bangladeshi $S$. dulcis, ${ }^{5)}$ have not yet been determined. The absolute configurations have to be ensured with respect to the proper correlations between structures and their biological 
Table 1. ${ }^{1} \mathrm{H}^{a}{ }^{a}$ and ${ }^{13} \mathrm{C}-\mathrm{NMR}$ Spectroscopic Data of 7 ( $\delta$ in ppm, $J$ in $\mathrm{Hz}$, $\mathrm{CDCl}_{3}$ )

\begin{tabular}{|c|c|c|}
\hline & $\mathrm{C} / \mathrm{H}$ & 7 \\
\hline 1 & 34.1 & $\begin{array}{l}1.75 \mathrm{~m} \\
1.71 \mathrm{~m}\end{array}$ \\
\hline 2 & 19.3 & $\begin{array}{l}2.15 \mathrm{~m} \\
1.41 \mathrm{~m}\end{array}$ \\
\hline 3 & 38.9 & $\begin{array}{l}1.85 \mathrm{brd}(10.1) \\
0.98 \mathrm{~m}\end{array}$ \\
\hline 4 & 42.4 & \\
\hline 5 & 52.3 & $1.20 \mathrm{brs}$ \\
\hline 6 & 69.3 & $5.44 \mathrm{~d}(1.7)$ \\
\hline 7 & 34.8 & $\begin{array}{l}1.75 \mathrm{~m} \\
1.71 \mathrm{~m}\end{array}$ \\
\hline 8 & 29.4 & \\
\hline 9 & 53.0 & \\
\hline 10 & 39.1 & \\
\hline 11 & 37.8 & $\begin{array}{l}1.51 \mathrm{~d}(11.7) \\
1.14 \mathrm{~d}(11.7)\end{array}$ \\
\hline 12 & 43.6 & \\
\hline 13 & 74.7 & 3.33 br s \\
\hline 14 & 36.2 & $\begin{array}{l}1.35 \mathrm{~m} \\
1.21 \mathrm{~m}\end{array}$ \\
\hline 15 & 36.3 & $\begin{array}{l}1.35 \mathrm{~m} \\
1.21 \mathrm{~m}\end{array}$ \\
\hline 16 & 22.1 & $\begin{array}{l}1.72 \mathrm{~m} \\
1.26 \mathrm{~m}\end{array}$ \\
\hline 17 & 23.9 & $0.94 \mathrm{~s}$ \\
\hline 18 & 29.3 & $0.93 \mathrm{~s}$ \\
\hline 19 & 181.2 & \\
\hline 20 & 20.8 & $1.42 \mathrm{~s}$ \\
\hline $\mathrm{C}=\mathrm{O}$ & 165.9 & \\
\hline $1^{\prime}$ & 130.7 & \\
\hline $2^{\prime}, 6^{\prime}$ & 129.6 & $7.89 \mathrm{~d}(7.8)$ \\
\hline $3^{\prime}, 5^{\prime}$ & 128.3 & $7.33 \mathrm{~d}(7.8)$ \\
\hline $4^{\prime}$ & 132.7 & $7.43 \mathrm{t}(7.8)$ \\
\hline
\end{tabular}

a) Assignments were performed on the basis of the heteronuclear single quantum correlation (HSQC) spectrum of 7.

activities. Therefore, $\mathbf{6}$ was subjected to the modified Mosher's ester procedure to determine the absolute configuration of the hydroxyl group at C-3. ${ }^{18)}$ Negative $\Delta \delta_{S-R}$ value for $(S)-(-)$ - $\alpha$-methoxy- $\alpha$-trifluoromethylphenylacetic acid $[(S)$-MTPA] ester $(\mathbf{6 b})$ and $(R)-(+)-\alpha$-methoxy- $\alpha$-trifluoromethylphenylacetic acid $[(R)$-MTPA] ester $(\mathbf{6 a})$ of $\mathbf{6}$ was obtained for $\mathrm{H}_{3}-20$ on the left side of the MTPA plane, and positive values were obtained for $\mathrm{H}_{3}-19$ and $\mathrm{H}-6$ on the right side (Fig. 2), indicating that the absolute configuration at C-3 is $S$. Stereochemical assignments at other chiral centers of $\mathbf{6}$ were further correlated from axial H-3 $\left[\delta_{\mathrm{H}} 3.11\right.$ (dd, $J=8.9$, $6.2 \mathrm{~Hz})]$ on the basis of the NOESY spectrum. Essentially similar NOEs of 6 to those reported in ref. 5 , namely from $\mathrm{H}-$ 3 to $\mathrm{H}_{3}-18\left(\delta_{\mathrm{H}} 1.03\right)$ and $\mathrm{H}-5\left(\delta_{\mathrm{H}} 1.12\right)$, from H-5 to H-6 $\left(\delta_{\mathrm{H}}\right.$ 5.66), from $\mathrm{H}-2^{\prime}\left(\delta_{\mathrm{H}} 7.96\right)$ to $\mathrm{H}-19\left(\delta_{\mathrm{H}} 0.90\right)$ and $\mathrm{H}-20\left(\delta_{\mathrm{H}}\right.$ $1.44)$, and from $\mathrm{H}-20$ to $\mathrm{H}-8\left(\delta_{\mathrm{H}} 2.39\right)$ confirmed the absolute structure of $\mathbf{6}$ as shown in Fig. 1. On the basis of the co-occurrence with 6 , compounds 4,5 , and 7 were concluded to be of the same absolute configuration.

Compounds 4-7 showed potent $\mathrm{IC}_{50}$ of $2.5,2$, 4, and $50 \mu \mathrm{g} / \mathrm{ml}$, respectively, in the 3-[4,5-dimethylthiazol-2-yl]2,5-diphenyl-tetrazolium bromide (MTT) cytotoxic assay against KB cells. Next, we assayed compounds $\mathbf{4}-\mathbf{7}$ for their inhibition of NO production in the LPS/IFN $\gamma$-induced murine macrophages. The inorganic free radical NO is produced by the oxidation of L-arginine by $\mathrm{NO}$ synthase and its
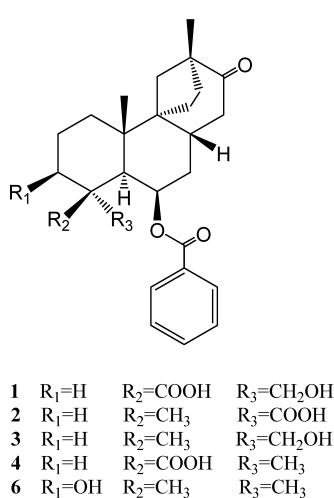

Fig. 1. Chemical Structures of $\mathbf{1}-\mathbf{7}$

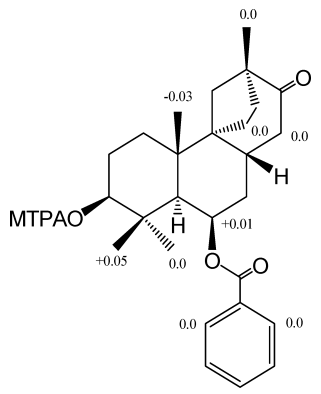

Fig. 2. $\Delta \delta_{\mathrm{S}-\mathrm{R}}$ Values (in ppm) Obtained for $(S)$ - and $(R)$-MTPA Esters $(6 \mathrm{~b}, \mathbf{a})$ of 6

overproduction can stimulate tumor growth and metastasis by promoting the migratory, invasive, and angiogenic potentials of tumor cells. ${ }^{6}$ However, weak activities were observed for 4-7 with $\mathrm{IC}_{50}$ of $150,50,100$, and $900 \mu \mathrm{g} / \mathrm{ml}$, respectively. The multidrug resistance (MDR) was also evaluated by calcein efflux studies. The membrane transport proteins belonging to the ATP-binding cassette (ABC) family such as P-glycoprotein (Pgp), which is encoded by the $m d r l$ gene, and members of the multidrug resistance associated protein family, especially MRP1, MRP2, and MRP3, are directly involved in this process. ${ }^{7)}$ The fluorescent organic anion calcein has been used as a probe of MRP activity in intact cells. In cellular studies, the acetoxymethyl ester of calcein (calcein-AM) given to cells diffused into the cells, where it was hydrolyzed to fluorescent calcein. In the present study, the diterpenoids 4-7 were able to moderately inhibit MRP at $\mathrm{IC}_{50}$ of $15,30,10$, and $20 \mu \mathrm{g} / \mathrm{ml}$, respectively. The $\mathrm{MIC}_{50}$ values of 4-7 against Escherichia coli, Bacillus subtillis, and Candida albicans, and 5-7 against Staphylococcus aureus and MRSA could not be determined because complete inhibition was not observed up to the concentration of $1 \mathrm{mg} / \mathrm{ml}$. Only selective inhibition of 4 against $S$. aureus $\left(\mathrm{MIC}_{50} 500 \mu \mathrm{g} / \mathrm{ml}\right)$, MRSA B26 strain $\left(\mathrm{MIC}_{50} 125 \mu \mathrm{g} / \mathrm{ml}\right)$, and the clinical isolate MRSA K1 strain $\left(\mathrm{MIC}_{50} 125 \mu \mathrm{g} / \mathrm{ml}\right)$ was observed.

\section{Experimental}

General Procedure Optical rotations were measured on a Union Giken PM-101 digital polarimeter. FT-IR spectra were recorded on a Horiba FT710 spectrophotometer. ${ }^{1} \mathrm{H}-(400 \mathrm{MHz})$ and ${ }^{13} \mathrm{C}-\mathrm{NMR}(100 \mathrm{MHz})$ spectra were obtained on a JEOL JNM $\alpha-400$ NMR spectrometer with tetramethyl silane as the internal standard. Negative-ion HR-FAB-MS were measured on a JEOL SX-102 mass spectrometer with PEG-400 as the calibration matrix. HPLC was carried out with a JASCO PU-1580 pump and UV-2075 Plus detector (set at $254 \mathrm{~nm})$ on YMC ODS columns $(150 \times 4.6 \mathrm{~mm}$ i.d. in analytical 
and $150 \times 20 \mathrm{~mm}$ i.d. in preparative scales) at the corresponding flow rates of 0.5 and $5 \mathrm{ml} / \mathrm{min}$. Silica gel $60(0.063-0.200 \mathrm{~mm}$, Merck) and YMC ODS gel were used for open column chromatography (CC). TLC was carried out on Merck TLC glass plates (silica gel $60 \mathrm{~F}_{254}$ ), and detected by spraying with $10 \% \mathrm{H}_{2} \mathrm{SO}_{4}$ in $50 \% \mathrm{EtOH}$, followed by heating on a hot plate at $200{ }^{\circ} \mathrm{C}$ $(R)-(+)$ - and $(S)-(-)$-MTPAs were purchased from Nacalai Tesque (Japan), 1-ethyl-3-(3-dimethylaminopropyl)carbodiimide hydrochloride (EDC) from Cica (Japan), and 4-dimethylaminopyridine (4-DMAP) from Wako Pure Chemical Industries (Japan).

Microorganisms The microorganisms used in this study Escherichia coli, Bacillus subtillus, Staphylococcus aureus, Candida albicans, and methicillin-resistant Staphylococcus aureus (MRSA) B26, and the clinical isolate strain MRSA K1 from patients of Hiroshima University Hospital (Hiroshima, Japan) were from the Collection of Professor M. Sugiyama of the Graduate School of Biomedical Sciences, Hiroshima University, Hiroshima (Japan).

Plant Material The dried aerial parts of $S$. dulcis were collected in the suburbs of Hanoi, Northern Vietnam, and identified by Dr. Tran Ngoc Ninh (Institute of Ecology and Biological Resources, Vietnam Academy of Natural Science and Technology, Hanoi, Vietnam) in January 2005. A voucher specimen (No. TNST 2005-1) is deposited in the Herbarium of the Institute of Ecology and Biological Resources.

Extraction and Isolation The dried and powdered aerial parts of $S$. dulcis $(1.0 \mathrm{~kg})$ were extracted with $\mathrm{MeOH}$ and the $\mathrm{MeOH}$ extract $(73.6 \mathrm{~g}) \mathrm{ob}$ tained was successively fractionated with $n$-hexane and $\mathrm{CH}_{2} \mathrm{Cl}_{2}$. On the basis of their similar TLC separation, the $n$-hexane- $(16.8 \mathrm{~g})$ and $\mathrm{CH}_{2} \mathrm{Cl}_{2}$-soluble fractions $(8.2 \mathrm{~g})$ were combined and fractionated by silica gel CC using $n$ hexane and $n$-hexane-EtOAc $(6: 1,3: 1,1: 1)$. Pooled fraction eluted with $n$-hexane-EtOAc (3:1) (3.8g) was subjected to successive separations on silica gel CC ( $n$-hexane-EtOAc, $2: 1)$ and ODS gel CC $\left(\mathrm{MeOH}-\mathrm{H}_{2} \mathrm{O}, 7: 3\right.$, 4:1), and preparative ODS HPLC $\left(\mathrm{MeOH}-\mathrm{H}_{2} \mathrm{O}, 7: 3\right)$ to give adrenalin (5.0 mg), 6-methoxybenzoxazolinone (180.5 mg), 4-epi-scopadulcic acid (4) $(12.1 \mathrm{mg})$, a mixture of lupeol and betulinic acid $(5.0 \mathrm{mg})$, nirtetralin $(6.3 \mathrm{mg})$, niranthin $(3.5 \mathrm{mg})$, and a mixture of dulcidiol (5) and scopadulcic acid C (7) (10.9 mg). The mixture of 5 and 7 was further separated by semipreparative HPLC on a polyamine II column (YMC, $250 \times 4.6 \mathrm{~mm}$ i.d.) using $\mathrm{MeCN}-\mathrm{H}_{2} \mathrm{O}(9: 1)$ to afford $5(7.0 \mathrm{mg})$ and $7(2.3 \mathrm{mg})$. The same treatment of pooled fraction eluted with $n$-hexane-EtOAc $(1: 1)(3.8 \mathrm{~g})$ gave 4',5-dihydroxy-3,7-dimethoxyflavone $(2.0 \mathrm{mg})$, acacetin $(3.0 \mathrm{mg}), 3$ '-hydroxy-4',5,7-trimethoxyflavone $(1.0 \mathrm{mg})$, and iso-dulcinol (6) $(9.1 \mathrm{mg})$.

Iso-dulcinol (6): Amorphous powder. ${ }^{1} \mathrm{H}-\mathrm{NMR}\left(\mathrm{CDCl}_{3}\right)^{19)} \delta$ : $0.90(3 \mathrm{H}, \mathrm{s}$, $\left.\mathrm{H}_{3}-19\right), 1.02\left(1 \mathrm{H}, \mathrm{s}, \mathrm{H}_{3}-17\right), 1.03\left(3 \mathrm{H}, \mathrm{s}, \mathrm{H}_{3}-18\right), 1.12(1 \mathrm{H}, \mathrm{d}, J=2.0 \mathrm{~Hz}, \mathrm{H}-$ 5), $1.44\left(3 \mathrm{H}, \mathrm{s}, \mathrm{H}_{3}-20\right), 1.48(1 \mathrm{H}, \mathrm{d}, J=12.0 \mathrm{~Hz}, \mathrm{H}-11 \mathrm{a}), 1.55(1 \mathrm{H}, \mathrm{dt}, J=$ 12.7, 3.4 Hz, H-1a), 1.59 (1H, m, H-2a), 1.67 (1H, m, H-1b), 1.68 (3H, m, 2H-7, H-15a), 1.75 (1H, d, J=12.0 Hz, H-11b), 1.77 (1H, m, H-16a), 1.78 (1H, m, H-2b), 1.90 (1H, dd, $J=16.4,12.0 \mathrm{~Hz}, \mathrm{H}-14 \mathrm{a}), 2.01$ (1H, m, H-16b), $2.19(1 \mathrm{H}, \mathrm{dd}, J=16.4,6.1 \mathrm{~Hz}, \mathrm{H}-14 \mathrm{~b}), 2.39(1 \mathrm{H}, \mathrm{m}, \mathrm{H}-8), 3.11(1 \mathrm{H}, \mathrm{dd}, J=$ $8.3,6.8 \mathrm{~Hz}, \mathrm{H}-3), 5.66$ (1H, br s, H-6), 7.39 (2H, t, $\left.J=7.3 \mathrm{~Hz}, \mathrm{H}-3^{\prime}, \mathrm{H}-5^{\prime}\right)$, $7.50\left(1 \mathrm{H}, \mathrm{t}, J=7.3 \mathrm{~Hz}, \mathrm{H}-4^{\prime}\right), 7.96\left(2 \mathrm{H}, \mathrm{d}, J=7.3 \mathrm{~Hz}, \mathrm{H}-2^{\prime}, \mathrm{H}-6^{\prime}\right) .{ }^{13} \mathrm{C}-\mathrm{NMR}$ data $\left(\mathrm{CDCl}_{3}\right)$ were superimposable with literature data. ${ }^{5}$ Negative-ion HRFAB-MS: $m / z$ 423.2574 [M-H] ${ }^{-}$(Calcd for $\mathrm{C}_{27} \mathrm{H}_{35} \mathrm{O}_{4}$ : 423.2594).

Scopadulcic acid C (7): Amorphous powder. $[\alpha]_{\mathrm{D}}^{25}-21.7^{\circ}(c=0.23$, $\mathrm{CHCl}_{3}$ ). IR $v_{\max }$ (film) $\mathrm{cm}^{-1}: 3592-2651,3430,3064,2929,2865,1706$, 1456, 1384, 1280, 1108, 1025, 756. ${ }^{1} \mathrm{H}$ - and ${ }^{13} \mathrm{C}-\mathrm{NMR}$ : see Table 1 . Negative-ion HR-FAB-MS: $m / z$ 439.2461 $[\mathrm{M}-\mathrm{H}]^{-}$(Calcd for $\mathrm{C}_{27} \mathrm{H}_{35} \mathrm{O}_{5}$ : 439.2484).

Preparation of $(R)$ - and $(S)$-MTPA Esters $(6 a, b)$ from Iso-dulcinol (6) A solution of $6(4.1 \mathrm{mg})$ in $1 \mathrm{ml}$ of dehydrated $\mathrm{CH}_{2} \mathrm{Cl}_{2}$ was reacted with $(R)$ MTPA $(50 \mathrm{mg})$ in the presence of EDC $(36 \mathrm{mg})$ and 4-DMAP $(40 \mathrm{mg})$ and the resulting mixture was occasionally stirred at $25^{\circ} \mathrm{C}$ for $24 \mathrm{~h}$. After the addition of $1 \mathrm{ml}$ of $\mathrm{H}_{2} \mathrm{O}$ and $1 \mathrm{ml}$ of $\mathrm{CH}_{2} \mathrm{Cl}_{2}$, the solution was washed successively with $5 \% \mathrm{HCl}, \mathrm{NaHCO}_{3}$-saturated $\mathrm{H}_{2} \mathrm{O}$, and brine. The organic layer was dried over $\mathrm{Na}_{2} \mathrm{SO}_{4}$ and then evaporated under reduced pressure. The residue was purified by silica gel CC ( $n$-hexane-EtOAc, $4: 1$ ) to give the ester, $6 \mathbf{a}(2.3 \mathrm{mg})$. Using a similar procedure, $\mathbf{6 b}(5.0 \mathrm{mg})$ was prepared from $6(3.5 \mathrm{mg})$ with $(S)$-MTPA $(50 \mathrm{mg})$, EDC (36 mg) and 4-DMAP (40 mg).

Iso-dulcinol $(R)$-MTPA Ester (6a): Amorphous powder. ${ }^{1} \mathrm{H}-\mathrm{NMR}\left(\mathrm{CDCl}_{3}\right)$ $\delta$ : $0.85\left(3 \mathrm{H}, \mathrm{s}, \mathrm{H}_{3}-19\right), 0.92\left(3 \mathrm{H}, \mathrm{s}, \mathrm{H}_{3}-17\right), 1.03\left(3 \mathrm{H}, \mathrm{s}, \mathrm{H}_{3}-18\right), 1.47(3 \mathrm{H}, \mathrm{s}$, $\left.\mathrm{H}_{3}-20\right), 1.92(1 \mathrm{H}$, dd, $J=16.1,12.2 \mathrm{~Hz}, \mathrm{H}-14 \mathrm{a}), 2.03(1 \mathrm{H}, \mathrm{brd}, J=13.9 \mathrm{~Hz}$, $\mathrm{H}-16 \mathrm{a}), 2.20$ (1H, dd, $J=16.1,6.4 \mathrm{~Hz}, \mathrm{H}-14 \mathrm{~b}), 3.48\left(3 \mathrm{H}, \mathrm{s},-\mathrm{OCH}_{3}\right), 4.59$ (1H, brs, H-3), 5.64 (1H, br s, H-6), $7.19-7.50(8 \mathrm{H}, \mathrm{m}$, aromatic protons), $7.93\left(2 \mathrm{H}, \mathrm{d}, J=7.2 \mathrm{~Hz}, \mathrm{H}-2^{\prime}, \mathrm{H}-6^{\prime}\right)$

Iso-dulcinol (S)-MTPA Ester (6b): Amorphous powder. ${ }^{1} \mathrm{H}-\mathrm{NMR}\left(\mathrm{CDCl}_{3}\right)$ $\delta: 0.90\left(3 \mathrm{H}, \mathrm{s}, \mathrm{H}_{3}-19\right), 0.92\left(3 \mathrm{H}, \mathrm{s}, \mathrm{H}_{3}-17\right), 1.03\left(3 \mathrm{H}, \mathrm{s}, \mathrm{H}_{3}-18\right), 1.44(3 \mathrm{H}, \mathrm{s}$,
$\left.\mathrm{H}_{3}-20\right), 1.92(1 \mathrm{H}, \mathrm{dd}, J=16.1,11.7 \mathrm{~Hz}, \mathrm{H}-14 \mathrm{a}), 2.03(1 \mathrm{H}, \mathrm{brd}, J=13.4 \mathrm{~Hz}$, H-16a), $2.21(1 \mathrm{H}, \mathrm{dd}, J=16.1,5.9 \mathrm{~Hz}, \mathrm{H}-14 \mathrm{~b}), 3.48\left(3 \mathrm{H}, \mathrm{s},-\mathrm{OCH}_{3}\right), 4.67$ (1H, br s, H-3), 5.65 (1H, br s, H-6), 7.19-7.50 (8H, m, aromatic protons), $7.93\left(2 \mathrm{H}, \mathrm{d}, J=7.2 \mathrm{~Hz}, \mathrm{H}-2^{\prime}, \mathrm{H}-6^{\prime}\right)$.

Antibacterial Susceptibility Assay Susceptibility tests were performed using a broth microdilution assay according to National Committee for Clinical Laboratory Standards (NCCLS) reference methods. ${ }^{20)}$ Assays were performed using Mueller-Hinton broth (Difco). The bacterial inocula were adjusted to yield a density of $5 \times 10^{5}$ colony forming units $(\mathrm{CFU}) / \mathrm{ml}$. Samples were diluted directly in 96-well microtiter plates by serial 2-fold dilution using a multichannel pipette. Microtiter plates were incubated during $24 \mathrm{~h}$ at $35^{\circ} \mathrm{C}$ and were read using a microtiterplate reader (Molecular Devices) at $620 \mathrm{~nm}$ as well as by visual observation. The $\mathrm{MIC}_{50}$ was determined as a $50 \%$ decrease in the optical density. Amphotericin B, penicillin G, and streptomycin were used as positive controls.

Antifungal Succeptibility Assay against Candida albicans Broth microdilution testing was performed according to the guidelines in NCCLS document M27-A2 ${ }^{21)}$ by using the spectrophotometric method of inoculum preparation, an inoculum concentration of $1.5 \times 10^{3}$ cells $/ \mathrm{ml}$, and RPMI 1640 medium buffered to $\mathrm{pH} 7.0$ with $0.165 \mathrm{~m}$ morpholinepropanesulfonic acid buffer. Samples were diluted directly in 96 well microtiter plates by serial 2 fold dilution using a multichannel pipette. Microtiter plates were incubated for $24 \mathrm{~h}$ at $35^{\circ} \mathrm{C}$ and were read using a microtiterplate reader (Molecular Devices) at $620 \mathrm{~nm}$. Amphotericin B, penicillin G, and streptomycin were used as positive controls.

MTT Cytotoxicity Assay This assay was performed using human epidermoid carcinoma KB cells and the viability was estimated by the colorimetric MTT assay. ${ }^{22)}$ Dulbecco's modified Eagle medium (DMEM) supplemented with $10 \%$ heat-inactivated fetal bovine serum (FBS) and $100 \mu \mathrm{g} / \mathrm{ml}$ of kanamycin and $0.5 \mu \mathrm{g} / \mathrm{ml}$ of amphotericin B were used as the cell culture medium. The test compounds were dissolved in DMSO and added to the each well of the 96 -well micro-titration plates at $1 \%$ as the final concentration. $\mathrm{KB}$ cells $\left(5 \times 10^{3}\right.$ cells/well) were cultured in a $\mathrm{CO}_{2}$ incubator at $37^{\circ} \mathrm{C}$ for $72 \mathrm{~h}$ and then MTT solution was added to each well and the plates incubated for a further $4 \mathrm{~h}$. The viability was compared to that of control cells incubated in the same medium without the test compounds. The cytotoxic activity was evaluated as the $\mathrm{IC}_{50}$ (the concentration of the compound required for $50 \%$ inhibition of cell growth). Mitomycin $\mathrm{C}$ was used as a positive control, which showed $50 \%$ inhibition at $10 \mathrm{ng} / \mathrm{ml}$.

Measurements of NO Production in LPS/IFN $\gamma$-Induced Murine Macrophage Cells Murine macrophage cell line RAW 264.7 was obtained from American Type Cell Culture Collection. RAW 264.7 cells were cultured in plastic dishes containing DMEM supplemented with $10 \%$ FBS in a humidified incubator containing $5 \% \mathrm{CO}_{2}$. The cells were cultured in 96-well plates $\left(5 \times 10^{5}\right)$ containing DMEM supplemented with $10 \%$ FBS for $24 \mathrm{~h}$ to become nearly confluent. The cells were then cultured with DMSO as a vehicle or samples in the presence of stimuli of LPS $(10 \mu \mathrm{g} / \mathrm{ml}) / \mathrm{IFN} \gamma$ $(20 \mathrm{ng} / \mathrm{ml})$ for $24 \mathrm{~h}$. Nitrite production, an indicator of NO synthesis, was measured in the culture supernatant of macrophages, as described previously ${ }^{23}$ using Griess reagent. Optical density at $550 \mathrm{~nm}$ was measured using a microplate reader (Molecular Devices).

Calcein Efflux Assay Calcein efflux assay was performed using a previously described method ${ }^{24)}$ with minor modifications to exclude possible side effects of test compounds on the uptake of calcein. A human erythroleukemia cell line, K562, was used for this assay. The cells were labeled with calcein-AM (Invitrogen) according to the instructions of the manufacturer. Then $2 \times 10^{4}$ labeled cells were seeded in each well of 96 -well microtiter plates with or without the test compounds. After a $4 \mathrm{~h}$ culture, the supernatant was harvested and the released fluorescence with excitation at $485 \mathrm{~nm}$ and emission at $530 \mathrm{~nm}$ was measured. Verapamil $(10 \mu \mathrm{M})$ and probenecid $(2.5 \mathrm{~mm})$ were used as the reference compounds and showed $71.7 \%$ and $37.0 \%$ inhibition, respectively.

Acknowledgments This work was supported by a Grant-in-Aid from the Japan Society for the Promotion of Science (JSPS). P.M.G. gratefully acknowledges the JSPS and the International Foundation for Science (Stockholm, Sweden) for financial support. The authors wish to thank the Research Center of Molecular Medicine of the Hiroshima University Faculty of Medicine, Japan, for the use of its NMR. We are grateful to Professor M. Sugiyama of the Graduate School of Biomedical Sciences, Hiroshima University (Hiroshima, Japan) for the kind gifts of methicillin-resistant Staphylococcus aureus (MRSA) B26 and the clinical isolate MRSA K1 from patients of Hiroshima University Hospital. We also wish to thank Miss Naoko Tamaki for carrying out the multidrug resistance assay, Miss Shiori 
Kawakami for the MTT cytotoxic assay, and Miss Hitomi Sumioka for the NO production assay.

\section{References and Notes}

1) Hayashi T., Okamura K., Kakemi M., Asano S., Mizutani M., Takeguchi N., Kawasaki M., Tezuka Y., Kikuchi T., Morita N., Chem. Pharm. Bull., 38, 2740-2745 (1990).

2) Ahmed M., Jakupovic J., Phytochemistry, 29, 3035-3037 (1990).

3) Hayashi T., Asano S., Mizutani M., Takeguchi N., Kojima T., Okamura K., Morita N., J. Nat. Prod., 54, 802-809 (1991).

4) Hayashi T., Hayashi K., Asano S., Takeguchi N., Horie S., Watanabe K., Miyahara T., Sankawa U., "Towards Natural Medicine Research in the 21th Century," ed. by Ageta H., Aimi N., Ebizuka Y., Fujita T., Honda G., Elsevier Science B. V., Amsterdam, 1998, pp. 197-205.

5) Ahsan M., Islam SK. N., Gray A. I., Stimson W. H., J. Nat. Prod., 66, 958-961 (2003).

6) Lala P. K., Chakraborty C., Lancet Oncol., 2, 149-156 (2001).

7) Deeley R. G., Cole S. P. C., Semin. Cancer Biol., 8, 193-204 (1997).

8) Johnson L. F., Jankowski W. C., "Carbon-13 NMR Spectra. A Collection of Assigned, Coded, and Indexed Spectra," Robert E. Krieger, New York, 1978.

9) Chen C. M., Chen M. T., Phytochemistry, 15, 1997-1999 (1976).

10) Mahato S., B. Kundu A. P., Phytochemistry, 37, 1517-1575 (1994)

11) Chang C. C., Lien Y. C., Chen Liu K. C. S., Lee S. S., Phytochemistry, 63, 825-833 (2003).

12) Rossi M. H., Yoshida M., Maia J. G. S., Phytochemistry, 45, 1263 1269 (1997).

13) Markham K. R., Geiger H., "The Flavonoids. Advances in Research since 1986," ed. by Harborne J. B., Chapman \& Hall, London, 1994, pp. $441-497$.

14) Nugroho B. W., Edrada R. A., Wray V., Witte L., Bringmann G., Gehling M., Proksh P., Phytochemistry, 51, 367-376 (1999).

15) Mahato S. B., Das M. C., Sahu N. P., Phytochemistry, 20, 171-173 (1981).

16) Kawasaki M., Hayashi T., Arisawa M., Morita N., Berganza L. H., Phytochemistry, 27, 3709-3711 (1988).

17) Li Y., Chen X., Satake M., Oshima Y., Ohizumi Y., J. Nat. Prod., 67 $725-727$ (2004)

18) Ohtani I., Kusumi T., Kashman Y., Kakisaws H., J. Am. Chem. Soc., 113, 4092-4096 (1991).

19) The assignment of the proton chemical shifts of 6 were reported here in detail with the help of ${ }^{1} \mathrm{H}-{ }^{1} \mathrm{H}$ Correlation Spectroscopy (COSY).

20) NCCLS: Methods for dilution of antimicrobial susceptibility tests for bacteria that grow aerobically. Fourth Edition; Approved Standard. NCCLS Document M7-A4, Vol. 17, No. 2, 1997.

21) Reference method for broth dilution antifungal susceptibility testing of yeasts. Approved standard M27-A2, 2nd ed. NCCLS, Wayne, Pa., 2002.

22) Carmichael J., DeGraff W. G., Gazdar A. F., Minna J. D., Mitchell J. B., Cancer Res., 47, 939-942 (1987).

23) Dirsch V. M., Stuppner H., Vollmar A. M., Planta Med., 64, 423-426 (1998).

24) Van Zanden J. J., Wortelboer H. M., Bijlsma S., Punt A., Usta M., Bladeren P. J., Rietjens I. M., Cnubben N. H., Biochem. Pharmacol., 69, 699-708 (2005) 